\title{
Religious Conflicts in Nigeria: Between Secularism and State Preference for Religions
}

\author{
Odoma Samuel1, Ngozi Obeta Anadi² \\ ${ }^{1}$ Department of Sociology, Bingham University, Karu, Nigeria \\ ${ }^{2}$ Department of Criminology and Security Studies, Nile University of Nigeria, Abuja, Nigeria \\ Email: odoma42@yahoo.com, anadi.ngozi@nileuniversity.edu.ng
}

How to cite this paper: Samuel, O., \& Anadi, N. O. (2021). Religious Conflicts in Nigeria: Between Secularism and State Preference for Religions. Open Journal of Social Sciences, 9, 20-37. https://doi.org/10.4236/jss.2021.91002

Received: October 19, 2020

Accepted: January 10, 2021

Published: January 13, 2021

Copyright $\odot 2021$ by author(s) and Scientific Research Publishing Inc. This work is licensed under the Creative Commons Attribution International License (CC BY 4.0).

http://creativecommons.org/licenses/by/4.0/ (c) (i) Open Access

\begin{abstract}
Religious motivated conflicts have become widespread in Nigeria, a nation considered by many to be one of the most religious nations of the world. Although it has been stressed that religion has the ability to bind people from different social backgrounds into a single moral community, the assertion came with a warning that, if not carefully handled, religion can equally disintegrate a society as much as it is believed to bind. This work chronicles religious practice and the corresponding conflicts in Nigeria, a nation that is clearly defined by its constitution as a secular state. Every segment of public life and policy is viewed through religious lens. Adopting the Functionalist perspective as base, the paper asserts that religious practice has become dysfunctional to the nation as a result of state's preference for the duo of alien but popular religions of Christianity and Islam in a secular state. Although, religious conflicts in Nigeria is endemic in the northern part, the entire nation has suffered from the impacts of its abuses such as insecurity and poor economic performance. It is recommended that constitutionalism be enthroned in the country to allow for a clear separation of religion from public lives of the people.
\end{abstract}

\section{Keywords}

Alien, Conflicts, Christianity, Islam, Preference, Religion, Secular

\section{Introduction}

One trait that is peculiar to human society across generations and which clearly mark mankind from other primates believed to have evolved from same ancestors is culture. Human beings are products of their cultures; hence man and his 
culture are inseparable. Culture differentiates humans from such primates as the Chimpanzees, Apes and Monkeys (Onwuejeogwu, 1992; Oke, 2002). One attribute of human culture is belief in the Supreme Being. Human beings across generations have practiced one form of religious belief or the other in an attempt to explain or answer some questions generated by their interactions with physical and social environments. A foremost Sociologist Emile Durkheim (1976) cited in Giddens (2009) defines religion as "a cultural system of commonly shared beliefs and rituals that provides a sense of ultimate meaning and purpose by creating an idea of reality that is sacred, all-encompassing and supernatural". Furthermore, Durkheim succinctly posit that "religion is a unified system of beliefs and practices relative to sacred things, that is to say, things set apart and forbidden-beliefs and practices which unite into one single moral community all those who adhere to them" (Kendall, 1996). Like many societies, the Nigerian state is identified with indigenous and imported religions with the imported religions (Christianity and Islam) dominating the religious lives of majority of the citizens (Akinola, 2004).

Religious practice is so endemic in Nigeria to the extent that scholars have clad Nigerians as the most religious people in the world (BBC News, 2004). This religious "height" of Nigerians notwithstanding, the nation equally "stand tall" among corrupt nations of the world (Human Right Watch, 2005, 2018, 2019). Not only is the giant of Africa unable to check the moral decadence of her citizens, but the practice of religions particularly the imported ones (Christianity and Islam) have been responsible for repeated conflicts that have claimed the lives of millions of citizens and destruction of properties worth billions of Naira mostly in the Northern parts of the nation (Imam, 2004; Odoma, 2014).

The Constitution of the Federal Republic of Nigeria 1999 as amended, Chapter 1 Section 10 states that "the government of the Federation or a State shall not adopt any religion as a state religion". Furthermore, Section 38 (1) states that:

Every person shall be entitled to freedom of thought, conscience and religion, including freedom to change his religion or belief and freedom (either alone or in community with others, and in public or private) to manifest and propagate his religion or belief in worship, teaching, practice and observance.

Section 38 (2-4) provides further clarifications that make the rules guiding any religious practice unambiguous in Nigeria. Yet, inter and intra religious conflicts have become one of the defining characteristics of Nigeria particularly the Northern part in the past three to four decades (Kukah, 1994; Imam, 2004).

What is however more disturbing is the fact that, it appears the Nigerian state have in principle adopted the duo of Christian and Islamic faiths as state religions in a country that is clearly defined secular by her constitution. Every sphere of our public life is visibly guided, manipulated and viewed with the lens of Christian and Islamic religions. A careful look at the political parties and their choice of candidates for electoral offices since our return to democratic practice in 1999 
depicts a systematic adoption of the two foreign but dominant faiths as state religions. If for instance, a presidential candidate of a party is a Muslim, the running mate compulsorily will be a Christian and vice versa. Where the Senate President is a Christian, his deputy must be a Muslim. If the Senate President is a Christian, the Speaker of the House of Representative must be a Muslim. The same unofficial political arrangement operates in the states with the exception of states from the extreme North and South-eastern Nigeria where these religions predominate. In fact, during the preparation for the 2015 general elections in Nigeria, a onetime president (Olusegun Obasanjo) publicly rejected a MuslimMuslim or Christian-Christian presidential ticket. His reason was that, such arrangement was dangerous to the polity (Olatunji, 2014). To ex-president Obasanjo as it is to most politicians in Nigeria, the nation is religiously very sensitive to allow the arrangement where the president and his vice belong to the same faith.

Furthermore, the Federal government of Nigeria has through its key policies and deployment of infrastructures since 1999 shown preference for Christian and Islamic religions. Some of these policies include the building of National Ecumenical Centre for Christians and its Islamic equivalent: the National Mosque and sponsoring of public functionaries to Israel and Saudi Arabia on annual pilgrimage. To prove government preference for these religions over and above others, public functions and occasions such National Day celebration is often commenced and concluded with opening and closing prayer alternated among these foreign religions. The government recruits, remunerates and fund clergymen from these religions. Nigeria today maintains such state officials as Chaplain of the State House Chapel, Imam of State House Mosque. The aforementioned state officials have often ensured that state policies are coated with religious flavor through their influence. The religion of the president and governors become the determinant of influence such clergymen can wield on public policies. Could this be the reason why some matters (including religious) appear not handled objectively in Nigeria? Have these religions become state religions in Nigeria? Have these religions become superior to other faiths in Nigeria? Does this arrangement go down well with citizens from other religions? These and other questions are the concern of this work.

\section{The Problem}

Although the constitution of the Federal Republic of Nigeria 1999 as amended clearly defines Nigeria a secular state, and that neither the Federal nor State government possess the power/right to declare any religious faith a state religion, several "unseen hands" and policies of governments at different levels appear to have made some religious faiths state religions. Since the return to representative democracy in 1999, sensitive political positions and policies of government in Nigeria have been made in favour of some specific religions. In fact, efforts to alter this unconstitutional development have met with stiff resistance of the political class. For instance, Olatunji (2014) reported the rejection by ex-president 
Olusegun Obasanjo and the political class of a Muslim-Muslim or ChristianChristian presidential ticket for candidates of political parties in preparation for the 2015 Presidential Election no matter their suitability. The adoption of Sharia law (an Islamic jurisprudence) for Zamfara State by Alhaji Ahmed Sani Yerima on 27 October, 1999 brought Nigeria face to face with the question of constitutional supremacy in Nigerian democracy. It appears that, when it comes to religious matters in Nigeria, the supremacy of the constitution cannot be guaranteed as many states (in the North) have equally followed the standard set by the Zamfara state government in adopting Islam as their state religion.

Even when it has often been denied by political actors, there are clear indications of state preference for Christian and Islamic religion in a multi-religious Nigeria. For instance, the Nigerian state has built places of worship for these religions as well as financing, recruiting and maintaining the Clergies that man them. The Federal, State and Local governments have often sponsored pilgrims to the holy lands with public funds (Janna, 2017). No doubt, a cold war has since been declared between the two religions on the control of the souls and psyches of those saddled with political leadership at all levels of governance in Nigeria. Politicians have often capitalized on this political misnomer to gain cheap popularity and identity in their quest to capture political power (Kukah, 1993; Akinola, 2011). The longer this is allowed to continue, the worse it will be for Nigeria and Nigerians to do objective political recruitment for our democratic institutions. Where religious sentiments become the major determinant of political recruitment, religious conflicts are bound to occur and when they do occur, the same sentiments may hinder objective handling of such conflicts and thus endanger the lives of citizens.

\section{Theoretical Underpinning}

The paper derives inspiration from the Functionalist perspective. Functionalists, particularly the structural functionalists perceive human society as a system. They equate society with a biological organism which although appear as an entity, is made-up of several distinctive parts that perform interrelated cum interdependent roles to sustain the entire structure in the performance of its functional prerequisites to the parts that constitute it (Wallace \& Wolf, 1995). The society is therefore a product of interrelated parts known as social institutions. The institutions include the family, religion, education, legal etc all working distinctively but interdependently in sustaining the society. The social system has an in-built mechanism that function to stabilize the entire system in the event of a malfunction of any of the parts (institution).

Applying the functionalist position, the religious institution is no doubt a vital part of the social system believed to be responsible for cohesion and social solidarity that the society need for the realization of its functional prerequisite of social reproduction. Problems with religion no doubt affect the effective functioning of the Nigerian social system. It is believed that, the stabilization forces of the 
system will eventually workout social equilibrium for the system. The ultimate responsibility of religious institution is however dependent on what Nigerian society makes of it. Structural functionalists posit that the functions that an organism perform is a product of its structure, if not such organism become dysfunctional. Hence, it has been argued that, if not well-structured religion can disintegrate as much as it is believed to bind a people into a formidable moral community (Giddens, 2009; Odoma, 2014). It certainly appears that unless the structure of the religious institution undergoes a critical review, it may not cease to be dysfunctional to Nigerian social system as experience have shown in the past three decades.

\section{Conceptualization}

Central to the discourse in this paper are the concepts of religion and secularism. The concepts are hereby presented as intended.

\section{Religion}

Several scholars have attempted to provide explanation/define the concept of religion. Tylor (1871) defines religion as the belief in spiritual things and the institutions and practices associated with those beliefs (Collins Dictionary of Sociology, 2000). However, Sociologists have come to identify with the explanation proffered by Emile Durkheim (1947/1912). He defines religion as a system of beliefs, symbols and rituals, based on some sacred or supernatural realm, that guides human behavior, giving meaning to life, and unites believers into a community (Kendall, 1996). Religion therefore refers to all efforts of man in collaboration with others at understanding and interpreting the puzzles faced in the course of interacting with his social and physical environments.

\section{Secularism}

The Collins Dictionary of Sociology (2000) posits that secularization refers to the practice in modern societies wherein religious ideas and organizations tends to lose relevance or influence as a result of the evolution of science and other forms of knowledge that tends to proffer solution to man's problem. Secularism therefore means the belief that religion should have no place in public affairs. In a secular state and formal organization, state and its functionaries are expected to distant self from any form of religious attachment or sentiments to avoid subjectivity in service delivery.

\section{Methods and Materials}

This paper is purely a product of a qualitative study. It dwells basically on qualitative data generated from historical antecedents, publications of past works, periodicals, journals, oral evidence of eye witnesses, observation and assessment of political and religious actors in the Nigerian social system. Data generated from across the nation were systematically arranged and analyzed using the qualitative methods of data analysis such as the content analysis and ethnographic summaries of the observed religious practices and their corresponding violent 
outcomes. Consequently, inference that informed the conclusion and recommendations were made on the strength of these ethnographic models. The qualitative method was considered ideal for the study, since it enhance robust collection of information on belief, cultural practices and group or inter group relations in Nigeria.

\section{The Literature}

No social problem has embarrassed Nigeria and Nigerians in the recent past like religious crises. The conflicts have left on its trail destruction to places of worship, loss of millions of lives and destruction to properties. The worse affected part is the Northern Nigeria where over fifty (50) of such crises have occurred in the past two-three decades leading to colossal losses of thousands of lives and properties belonging to public and private individuals (Abimboye, 2009; Odoma, 2014). Table 1 below clearly shows the intensity and the level of human and material losses incurred in some selected ethno-religious conflicts in Northern Nigeria.

\section{Causes of Religious Conflicts Nigeria}

Some factors can be held accountable for the recurrent violent religious conflicts in Nigeria and Northern Nigeria in particular. Prominent among them are:

\section{a) Governmental preference for religions}

There several religious groups in Nigeria. Some of these religious groups are indigenous while others are alien to the nation (Akinola, 2011). Religious belief ought to be a matter of personal conviction and faith. The expansion or otherwise of any of the faiths should ordinarily be a function of personal conviction arising from the practice of religious piety by adherents of each religion (Odoma, 2014). If this has been the case in Nigeria, there would have been little or no friction between and within religious groups as witnessed in the recent past. However, the government and its functionaries have over the years given undue preference and relevance to some religious groups particularly, Christian and Islamic religions. Political and public officials have not been able to separate themselves from their religions while in office as expected in a secular state, but have often dragged religion into politics, thus tactically forcing non-adherents into their religions through tact, deceit and outright denial or victimization of people when it comes to accessing dividends of governance (Toure, 2003). The implication of this unconstitutional practice has always been that the religions of political and public officials become the popular religion. Citizens are made to practice or adopt such religions in other to attract the sympathy, favour, and dividends of governance. Those who behave otherwise (adherents of other religions) have been considered inferior, unbeliever and discriminated against (Kukah, 1994; Toure, 2003; Odoma, 2014). Many no doubt may have found themselves in some religious groups so as to please their bosses and avoid victimization. If and when such becomes the basis for religious practice, naivety and mediocrity which propels violent religious conflicts become widespread in religiously volatile 
Table 1. Some cases of ethno-religious conflicts in northern Nigeria.

\begin{tabular}{|c|c|c|c|}
\hline S/N & DATE & LOCATION & LOSSES INCURED \\
\hline 1. & 21 February, 2000 & Kaduna & $\begin{array}{l}\text { Religious riots between Christians and Muslims over the introduction of Sharia law in Kaduna } \\
\text { State. Between } 2000 \text { - } 5000 \text { lost their liv es. }\end{array}$ \\
\hline 2. & $\begin{array}{l}7 \text { - } 17 \text { September, } \\
2001\end{array}$ & Jos & Religious riots between Christians and Muslims. Between 500 to 5000 persons lost their lives. \\
\hline 3. & $\begin{array}{l}22 \text { November, } \\
2002\end{array}$ & Kaduna & $\begin{array}{l}\text { Over } 200 \text { persons were killed and many religious houses burnt in inter religious conflict caused } \\
\text { by reactions to Miss World contest slated for Abuja. }\end{array}$ \\
\hline 4. & February, 2004 & Yelwa-Kano & Religiously motivated Killings between Christians and Muslims, about 975 persons killed. \\
\hline 5. & 18 February, 2006 & Maiduguri & $\begin{array}{l}\text { Over } 50 \text { people were killed while places of worship were destroyed by Muslim rioters as a result } \\
\text { of cartoon involving prophet Muhammad in a Danish News paper. }\end{array}$ \\
\hline 6. & $\begin{array}{l}28 \text { - } 29 \text { November, } \\
2008\end{array}$ & Jos & $\begin{array}{l}\text { Religious riots between Christians and Muslims over results of Local Government Elections. } \\
\text { Scores of people killed and places of worship destroyed. }\end{array}$ \\
\hline 7. & July, 2009 & $\begin{array}{l}\text { Maiduguri, Bauchi, } \\
\text { Potiskum \& Wudil }\end{array}$ & Boko Haram Crises where over a 1000 people were killed for refusing to convert to Islam \\
\hline 8. & 2010 & Jos & 992 persons were killed in a religious riots, most of the victims were Christians killed by Muslims. \\
\hline 9. & 4 November, 2011 & Damaturu & $\begin{array}{l}\text { Islamic Militants associated with Boko Haram attacked Police Stations and Churches, about } \\
200 \text { persons were killed. }\end{array}$ \\
\hline 10. & 25 December, 2011 & Madalla & Muslim militant bombed a Catholic Church during Christmas service about 7 persons were injured. \\
\hline 11. & 5 - 6 January, 2012 & $\begin{array}{l}\text { Maiduguri, Mubi, Yola } \\
\qquad \& \text { Gombi }\end{array}$ & Islamic terrorists attacked Churches and businesses, Boko Haram claimed responsibility. \\
\hline 12. & 20 January, 2012 & Kano & $\begin{array}{l}\text { Islamic terrorists attacked Churches and businesses killing scores. Boko Haram claimed } \\
\text { responsibility. }\end{array}$ \\
\hline 13. & 8 April, 2012 & Kaduna & Islamic terrorists bombed Churches on Easter, about 38 persons were killed. \\
\hline 14. & 17 June, 2012 & Kaduna & About 80 persons injured as Islamic terrorists attacked 3 Churches. \\
\hline 15. & August 2012 & Okene & Islamic terrorists attacked Deeper Life Church, the pastor was among 19 victims. \\
\hline 16. & 25 december, 2012 & $\begin{array}{l}\text { Maiduguri and } \\
\text { Potiskum }\end{array}$ & Islamic militant attacked Churches on Christmas day killing scores. \\
\hline 17. & 2 June, 2014 & Gwoza & Between 200 - 300 people were killed in Boko Haram attack on Christian villages. \\
\hline 18. & $\begin{array}{l}\text { Thursday, July } \\
22^{\text {nd }}, 1999\end{array}$ & Kano reprisal killing & $\begin{array}{l}\text { Hausa/Fulani youth took vengeance on the killing of their kith and kin in Sagamu. Their target } \\
\text { was the Yoruba community. }\end{array}$ \\
\hline 19. & February $28^{\text {th }}, 2000$ & $\begin{array}{l}\text { Kaduna mayhem } \\
\text { (Kaduna state) }\end{array}$ & $\begin{array}{l}\text { Kaduna city exploded in violence as Muslim and Christian extremists and other hoodlums } \\
\text { clashed over the proposal to introduce sharia. }\end{array}$ \\
\hline 20. & $\begin{array}{l}\text { Friday, April } 14^{\text {th }}, \\
\quad 2000\end{array}$ & $\begin{array}{l}\text { Agyragu crisis } \\
\text { (nasarawa state) }\end{array}$ & $\begin{array}{l}\text { Communal clash that started with a protest against the location of local government headquarters. } \\
\text { The militant youth group started the riot and later took to the streets, killing and destroying. }\end{array}$ \\
\hline 21. & July, 2000 & Tsagari crisis (kwara) & Clash Tsagari and share communities with kwara state which claimed several lives. \\
\hline 22. & $\begin{array}{l}\text { September } 8^{\text {th }} \text {, } \\
2000\end{array}$ & $\begin{array}{l}\text { Kaltungo religious } \\
\text { (gombe state) }\end{array}$ & $\begin{array}{l}\text { A religious violence that was sparked off by the presence of the states sharia implementation } \\
\text { committee. }\end{array}$ \\
\hline 23. & October $17^{\text {th }}, 2000$ & $\begin{array}{l}\text { OPC-Hausa/Fulani } \\
\quad \text { (Kwara) }\end{array}$ & $\begin{array}{l}\text { A face off between the militant members of OPC and Hausa/Fulani community over } \\
\text { supremacy of Emirate system in the state. }\end{array}$ \\
\hline 24. & $\begin{array}{l}\text { Saturday, October } \\
21^{\mathrm{st}}, 2000\end{array}$ & Minna reprisal (Niger) & Violent ethnic crisis erupted after the OPC assault in Kwara and Lagos states. \\
\hline 25. & $\begin{array}{c}\text { Saturday, } \\
\text { December } 02,2000\end{array}$ & Hadejia crisis (Jigawa) & $\begin{array}{l}\text { A sectarian disturbance that was caused by debate between a Muslim and a Christians in } \\
\text { Hadejia (Jigawa. There was wanton destruction of worship places. }\end{array}$ \\
\hline
\end{tabular}




\section{Continued}

26. Thursday, June $28^{\text {th }}, 2001$

27. Friday, September 07, 2001

28. October $12^{\text {th }}, 2001$

29. Monday, October $29^{\text {th }}, 2001$

30. Friday, November 02, 2001

31. Sunday, December 30, 2001

32. January $18^{\text {th }}, 2002$

33. May $2^{\text {nd }}, 2000$

34. Monday, may $27^{\text {th }}$ 2002

35. Saturday, June 01, 2002

36. Monday, July 01, 2002

37. Tuesday, July 01, Edo/Kogi 2003

38. Thursday, January $1^{\text {st }}, 2004$

39. Thursday, January $1^{\text {st }}, 2004$

40. Sunday, February $1^{\text {st }}, 2004$

41. Sunday, February $1^{\text {st }}, 2004$

42. Saturday, April $3^{\text {rd }}$, 2004

43. Sunday, April $11^{\text {th }}$, 2004

44. Monday, April $26^{\text {th }}, 2004$

45. Sunday, may $1^{\text {st }}$, 2004

\section{Azara crisis}

(Nasarawa)

Jos crisis

Kano riot

Tiv-Jukun/Fulani conflict

Gwantu crisis

Vwang crisis

Awe crisis

Jos Mayhem

Fulani-Irigwe crisis

Yelwa-Shendam mayhem (plateau)

Ganye, Adamawa

Yobe

Wase/Kanam

(Plateau)

Wase/Kanam

(Plateau)

Makarfi, Kaduna

Lantang South, Plateau

Bakin Chiyawa, Plateau
An ethnic conflict between the Tiv and the Azara indigenes. It started with gruesome killing of an Azara traditional leader, and later spread to the Tiv Village, with the Tiv community on the defense.

A violent ethnic religious crisis between the Muslim/Hausa Fulani and Christian indigenes. The subject of discord between the Jasawa Development Association and Plateau youth council was over political appointment in Jos North.

A peaceful Anti-American protest over the bombing of Afganistan turned violent, taking ethnic and religious dimensions, it degenerated into uncontrollable violence which claimed lives and damaged properties and places of worship.

An ethnic clash between Tivs and Jukuns/Fulani which was an extension of the may 2001 clash and could be linked to the protracted disputes between both sides. Newswatch reported that 16 soldiers were killed which later led to the gruesome revenge on the Tivs, by the Nigerian Army.

A clash that started on a political ground (over relocation of LG headquarters) later took on ethno-religious dimension in which places of worship were destroyed.

A violent communal conflict in Vwang district between the indigenes and non-indigenes, exploded in the backdrop of September 7 jos crisis. It started when an illegal group of 40 men attacked the district Head of Vwang. It also had religious colouring.

A renewed communal clash between two indigenous communities in Awe local government in Nasarawa state. The cause was not certain but two people were killed and several others injured.

Another mayhem that followed PDP congress but later took an ethno-religious colour.

An ethnic clash between the Hausa/Fulani and the Irigwe indigenes in Basa, plateau which was said to be a reprisal attack.

A religious-cum ethnic fracas between the native people (predominantly Christians) and Hausa settlers (predominantly Muslims). This violence extended to about four local government councils in southern plateau.

The Yelwa-Shendam riots spilled over to plateau

Communal clashes between border communities in Edo and Kogi states Ekepedo and Ogori over land ownership.

Clash between Fulani herdsmen and farmers over grazing lands.

Militant Islamic group operating under the name of Muhajiran launched a Tiliban-like attack on police. Men of the Nigerian Army killed five and arrested several others.

Violent clash between Mavo and Taroh communities which claimed 11 lives. Suspected Taroh youths were alleged to have raided Mavo villages.

Communal clash over land ownership between Minda and Kparev groups. Several lives were lost.

Religious protest in Makarfi town over the desecration of Quaran by a Christian teenager.

Continued clashes that led to the sacking of Taroh villages in Lantang South LGC by suspected Hausa/Fulani insurgents.

Renewed hostilities launched by suspected displaced Fulani herdsmen. The conflict was believed to be the spillover of the ethno-religious crisis that has been bedeviling southern plateau local governments of Lantang south and north, Wase, Kanam and Shendam.

Yelwa-shendam, A fresh ethno-religious mayhem that claimed over 659 lives and over 250 women abducted bu plateau state 


\section{Continued}

\begin{tabular}{|c|c|c|c|}
\hline 46. & $\begin{array}{l}\text { Wednesday, May } \\
112^{\text {th }}, 2004\end{array}$ & Kano & $\begin{array}{l}\text { Kano mayhem following the Yelwa shendam ethno-religious crisis in plateau. Non-Muslims } \\
\text { were attacked in reprisal of the plateau crisis. Over } 200 \text { lives were lost and the traditional ruler } \\
\text { of area deposed. }\end{array}$ \\
\hline 47. & $\begin{array}{l}\text { Saturday, June } 8^{\text {th }} \text {, } \\
\qquad 2004\end{array}$ & $\begin{array}{l}\text { Konshisha/Gwer, } \\
\text { Benue }\end{array}$ & $\begin{array}{l}\text { Boundary disputes between neighboring Konshisha and Gwer communities. Thirteen lives } \\
\text { were lost. }\end{array}$ \\
\hline 48. & $\begin{array}{l}\text { Teusday, June } 4^{\text {th }} \text {, } \\
\qquad 2004\end{array}$ & Numan, Adamawa & $\begin{array}{l}\text { Ethno-religioud crisis in Numan over the construction of mosque minaret over the Humma } \\
\text { Bachamas palace. Over } 50 \text { people were feared killed and the traditional ruler of the area deposed. }\end{array}$ \\
\hline 49. & $\begin{array}{l}\text { Tuesday, August, } \\
3^{\text {rd }}, 2004\end{array}$ & Quanpam, Plateau & $\begin{array}{l}\text { Fresh outbreak of violence in Lankaka village. Suspected armed militia from neighboring state } \\
\text { allegedly stormed the village community killing two and razing twenty houses. }\end{array}$ \\
\hline 50. & $\begin{array}{l}\text { Monday, } \\
\text { September } 27^{\text {th }} \text {, } \\
2004\end{array}$ & Limankara, Borna & $\begin{array}{l}\text { A self-styled Tiliban group hiding on the Goza hill and Madara mountains on the North-eastern } \\
\text { border with Cameroon raid police station killing officers and stealing ammunition. }\end{array}$ \\
\hline
\end{tabular}

Source: Adapted from Newswatch $2^{\text {nd }}$ November, 2009; Sampson, 2012. Casualty figures are in some cases approximated.

Nigeria. Such people are believed to constitute the nucleolus of those who kill others in the name of religion probably for being naïve and bereft of the basic tenet of religions they profess (Imam, 2004).

\section{b) Struggles for Superiority}

There is no doubt that one of the major causes of religious conflicts and the carnages that accompany their occurrence in Nigeria is the struggles by the two alien but populous religions-Christianity and Islam to outwit each other. Having been used by politicians as tool to rise to political prominence (Kukah, 1994), religious leaders often team-up with benefiting politicians to use their vantage political positions to outwit other religions and make them subservient to such privileged religion (Toure, 2003). This practice that has plagued the North-Central state of Kaduna was encouraged by colonial masters. Consequent upon this advantage enjoyed by some religious faiths, political recruitment processes are taken to places of worship where the faithful are encouraged to support their religious members in politics. Once such persons win the election, their religious groups enjoy patronage and superiority over and above others. Capitalizing on the role they play to religious groups; politicians equally enjoy such supports to remain in power as long as the support last. To religious groups therefore, ascendance of their co-faithful is a sure bet to prominence and a quick channel to proselyting and expansion. Other religious groups which are not in complete oblivion of this unconstitutional process may wish to enjoy same, leading to conflict which sometimes turns violet.

\section{c) Fear of Extinction and Loss of Hegemony}

The fear of possible extinction and loss of hegemony remains one of the critical factors that fuels violent religious conflicts particularly between Christians and Muslims in the northern parts of Nigeria. The two dominant religions hold sway or appear to have partitioned the nation into two parts following their routes into the country. While Islamic religion is dominant in the north, Christian religion is widely practiced in the south. The two have made frantic efforts at extending the frontiers of their dominance beyond their traditional enclaves 
(Crampton, 1976; Odoma, 2014). For instance, the dream of Uthman Danfodio's Jihad of the $17^{\text {th }}$ century was to dip the Quran into the Atlantic Ocean (Crampton, 1976) from the north where it gained entrance and had dominance. The religions have not abandoned their age-long expansionist dreams. More worrisome is the fact that the expansionist dream is pursued with vigor, mutual distrust and rivalry. Everything at their disposal including political power is employed to achieve this age-long aspiration such that they can retain their erstwhile hegemony. For instance, Kukah (1994: p. 153) reported the position of one Alhaji Dankwairo thus:

Since the time of Ahmadu Bello, there has never been another leader with power, except Alhaji Shehu Shagari, the trusted one. He is the grandson of the servant of God, he is a servant of god (Bawan Allah). My happiness is that, our flag which have been lying on the ground in Mecca, the reign of Alhaji Shehu Shagari has raised it up. In the face of Islam today in the whole world, Nigeria is the first.

The crux of the above quotation is that, there is a hegemonic link between Islamic religion and politics in Nigeria. Everything possible is done to sustain such hegemony, while whatever appears to stand against such perception is resisted. Adherents of other religions who by all standards are citizens with equal rights could contest such stance that could breed conflict.

\section{d) Politicization of Religion}

Having known the power of religion in influencing voting behaviour of electorates, Nigerian politicians have always sought to drag and do drag religion into Nigerian body politics, sometimes to gain cheap popularity (Kukah, 1994; Toure, 2003). Even though it is wrong to politicize religion, it has gradually become a part and parcel of our political arrangement as a people. Because of the large followership of the duo of Christian and Islamic religions, public policies are made to assume religious dimension. This has always raised "dust" in several parts of the nation. For example, Dr. Kayode Fayemi was sworn-in for the second time as governor of Ekiti State on Tuesday 16 October, 2018. By Wednesday 17 October, 2018, he made three key appointments into the state Executive. By Thursday 18 October, 2018, there were cacophony of voices from a religious group which claimed that, the appointments were skewed in favor of the religion of the governor. In reaction, the governor promised to ensure a balance in subsequent appointments. In the same vein, ex-president Olusegun Obasanjo has in 2014 advised against the selection of party's flag bearers for presidential election of 2015 from same religion. His reason was that such arrangement was dangerous in the religious sensitive Nigeria (Olatunji, 2014). Today, if a party appoints a Christian presidential candidate, his running mate must be a Muslim and vice versa. So, beside the quality, competence and capability to deliver, religious balancing has become critical in political recruitment and policy implementation in democratic Nigeria (Kukah, 1994). Ignoring religious balancing even in the face of obvious mediocrity can be a source of religious crisis in Nigeria. 


\section{e) Indecisive Management of previous Crises}

The recurrent cases of sectarian violence in Northern Nigeria have been linked to the inability of government and religious leaders to decisively handle previous crises (Kukah, 1994; Imam, 2004). While Kukah accused political and religious leaders basically because of their indifference stance at the time of the clashes, Imam (2004) blamed the security operatives of poor handling of some of those religious conflicts in Northern Nigeria. Succinctly, Imam (2004: pp. 36-37) avers that:

While victims of religious crises contend with their fates, police were reported to have harassed innocent citizens, chased them out of their houses before plundering them. Where the people resisted, they were killed and their properties looted. A few cases of police brutality were reported in Maiduguri and Jimeta crises. In Bullum-Kuttu Maitasine uprising for example, police were reported to have mounted road-blocks far away from the scene of the incidents and proceeded to molest innocent or fleeing people and robbed them of their properties. In Lamduri village, police brutality caused the residents lives of sixteen people including the village head $(\mathrm{Bu}-$ lama). In Jimeta crisis police were accused of chasing civilians out of their houses in the unaffected areas so that they could loot. In addition, police were reported to have pursued people into their houses and killed them even if such people were not physically seen at the scene of the crises. Coupled with the massacre was indiscriminate arrest of innocent citizens.

If the quotation above is anything go-by, it suggests dissatisfaction of victims of conflicts about governmental handling. This has encouraged bottled anger which often trigger other rounds of conflicts at slightest provocation.

Yet, lending credence to the allegation of poor handling of religious crises in Northern Nigeria, Kukah (1994: pp. 214-215) posits that:

Unfortunately, the destructions by Islamic fanatics continued to reinforce the belief in the minds of many non-Muslims that these evil deeds were being perpetrated by Islam. The apparent silence of the traditional and political classes among the Muslims further fuelled the feelings that they were the sponsors of these riots. Identities began to be narrowed and religion became the basis of identity. Thus, one was either a Muslim or a Christian, a fractionalisation that fitted the $U s$ and Them mentality that had gained prominence. ... Thus, it was not long before evangelicals and their rivals in the MSS, the Council of Ulama, Izala and members of African traditional religion, began to beat their war drums, accusing the government and members of ACRA of playing the ostrich in the matter under consideration.

\section{f) Ignorance}

Ignorance is no doubt a very dangerous disease. It is a silent killer and a destroyer of the society. Ignorance makes one an ardent believer of an idea channel every available resource is channeled into unreasonable quest, but ultimately 
ends in failure. If not well handled, it is capable of making one commit suicide. Imam (2004) identifies two forms of ignorance that have fuelled violent religious crises in Nigeria in the recent past. One is ignorance of other person's religion. What majority of Nigerian citizens care for is their own faith; they hardly know anything about the faith of others. This creates lack of respect for what others belief and live for. The best way to peacefully cohabit with someone is to understand the basic things that sustain him/her and then make efforts to respect such things. The failure to do this exposes one to frictions with neighbours. The second form of ignorance is ignorance of the religion one professes. Many Nigerians claims to be so religious and are ready to do anything in support of their faith, even if it means dying for their faith (BBC News, 2004). Yet, many are ignorant of the basic tenets of their religion. It is for instance, erroneously believed by some Muslims that, if they die fighting for their religion (Jihad), they are granted unhindered access to blissful life in paradise (Imam, 2004; Ibrahim, 2011). This belief makes some with shallow understanding to take pleasure in killing others and seeing nothing wrong with their colleagues being exposed to continuous hazards in society (Odoma, 2014). The questions begging for answers are, if you love your neighbour as the two religions (Islam and Christianity) in constant conflicts claims, would you want people to die to get to hell or be patient with them to be converted by your piety, so that they can be part of the celebrated paradise? The founders of these religions (Jesus and Mohammed) once lived on earth. Can any of their followers attest to the number of persons they killed while here on earth? Yet, they were hated and not a few of their contemporaries ignored their teachings and hated them for what they preached. People who kill in the name of obeying their religious injunctions may have to deal with ignorance of their religions.

\section{g) Fanaticism}

Fanatics are extremists who utilize aggression, intimidation and coercion in compelling people to see things their own way. They are equally uncomfortable with people who hold alternative or different views of what they believe. Fanatics can kill to satisfy their dogged position. Fanaticism is one of the factors responsible for religious crises in Nigeria (Imam, 2004). Most of the fanatics have shallow understanding of the faith they profess, but because of excessive zeal they display and their gullibility, they are easily lured into violent conflicts by influential others for little or no reward. In their quest to outwit each other, fanatics appear to be willing tools in the hands of religious leaders in the killing and destruction of non-adherents, their properties and places of worship. Religious conflict in the North such as the Maitasine riots and the ongoing Boko Haram terrorism are believed to be championed by religious fanatics (Toure, 2003).

\section{Major Findings}

Following from the analysis of this study, the underlisted were discovered as major findings. 
1) The Nigerian state has systematically preferred and adopted some religions as state religions in a country described by her constitution as a secular state. This finding is validated by the consistent and concerted state policies at giving prominence to only two religions (Christian and Islam) amidst several other religious groups in the country (Akinola, 2011).

2) The state have consistently recruited, maintained and sponsored clergymen with public funds on pilgrimages from the preferred religions to the detriment of other religious groups (Jana, 2017).

3) The channel for the actualization of religious preference has been through politics. Religion has therefore, become a powerful tool in the politics of Nigeria (Kukah, 1993; Akinola, 2011). This situation has equally politicized religious practice in Nigeria. This has produced fanatics who are largely ignorant of the tennent of religions they profess (Imam, 2004).

4) Some religious groups not favoured by the state have been involved in a "cold war" with the duo of Christian and Islamic religions. Yet, the preferred religions have equally been in hegemonic conflicts, leading to skirmishes in parts of the country.

5) Federal and state governments have since 1999, contested the supremacy of the constitution of the Federal Republic of Nigeria by openly and systematically preferring some religions over others.

6) Violent religious conflicts in Nigeria is worsen by ignorance of majority of adherents who only got lured into the preferred religions as the only way to enjoy dividends of democracy (Imam, 2004). Rather than personal conviction and reason, most religious Nigerians are lure into the practice of what they have little or no knowledge about (Odoma, 2014). This has encouraged the display of ignorance in religious practice, which have often turned violent particularly in Northern Nigeria (Imam, 2004).

\section{Implications for National Development}

There is no doubt that Nigeria is a religiously volatile nation. Although religious conflict is as old as the nation itself (Crampton, 1976), the intensity, frequency and the level of destruction to lives of citizens and their properties have assumed a disturbing dimension in the past two to three decades. There is hardly any year that at least two or more religious violence is not recorded in parts of the country (Odukoya, 2016). The notorious part of the country reputed for these crises is the North where adherents of Islamic and Christian religions have been involved in cut throat struggles for identity and superiority (Kukah, 1994; Toure, 2003; Imam, 2004; Odukoya, 2016). The latest and prolonged of such cases is the ongoing Boko Haram religious violence in the North-Eastern Nigeria. This bad reputation occasioned by repeated animosity between the dominant religions in the country has exposed the nation to grievous setbacks. These include among others discouragement of investors, economic disruption and dented image. 


\section{a) Discouragement of Investors}

One common experience with places where religious conflicts have occurred in Nigeria is wonton destruction of lives, personal and public properties. This has always created a problem of survival for people living in the affected areas in two basic ways. The first is how to contend with health challenges following physical injuries suffered. Not many could access medical facilities at the time of these crises due to threat to life and displacement from their traditional homes. Eventually, many died in the process. Secondly, arising from wonton destruction to public installations and investments, many who survived the health hazards had their sources of sustenance to contend with as businesses were either burnt or looted. Not many overcame such experiences as several businesses folded-up. This common experience has made investors to flee violent prone areas to places considered safe (Kukah, 1994; Odoma, 2014; Odukoya, 2016). The government of Buhari like its predecessors have traversed countries of the world encouraging investors to come and invest in the resource studded Nigerian economy (Odoma, 2014), yet, not many have heeded this overture as a result of frequent violence and the attendant huge Internally Displaced Persons (IDPs). Certainly, no investor (domestic or foreign) would want to invest in an economy that is full of violence and uncertainties.

\section{b) Economic Disruption}

Arising from repeated cases of religious violence, Nigeria is faced with huge problem of Internally Displaced Persons (IDPs). According to the Mid-year Reports of Internally Displaced Monitoring Center (IDMC), the nation generates one of the highest numbers of IDPs in the world today (IDMC, 2018). Rather than developing her ailing economy, millions of Naira is expended on maintaining numerous IDP centers, most of which are in deplorable conditions. About 90 percent of IDP centers in Nigeria today are located in the North where religious crises have been prevalent. Most of these centers are in serious humanitarian crises arising from poor funding and mismanagement (IDMC, 2018). The economy of that part of the country is at its lowest ebb. Certainly, no country develops following this path.

\section{c) Dented National Image}

The repeated violent religious conflicts in parts of Nigeria have dented the image of the nation in international community. Nigerians appear to be people given to religious extremism and violence. If reports coming out of the nation on a regular basis are linked to violence, kidnapping, assassination and their likes, not many will take the nation serous for what it claims to be in comity of nations. This explains why nations are skeptical to do serious business with Nigeria at the moment.

\section{d) Reduction of every Critical Issue to Religious Sentiment}

Religious conflicts in Nigeria appear to have beclouded objective reasoning of most citizens particularly the political elites when issues critical to national development are discussed. Virtually every issue is viewed with religious lens or 
subjected to religious sentiments and are thus not accorded the seriousness it deserves. For instance, in the wake of brutality of government and its agencies on Nigerian citizens, there were reactions from across the nation on the need for government to retrace its steps. Notable among groups that protested the obvious bad governance were the Nigerian Bar Association (NBA) and the Youths. Citing instances of maladministration and disregard for human rights by Mallam El-Rufai the governor of Kaduna State, some members of the NBA protested against the invitation of the governor as one of the guests at their national convention in 2020. Rather than view the complaint objectively, the protest surprisingly attracted religious sentiments of some members who threatened to form a parallel Bar Association. Their reason was that, Christian members had teamedup against the choice of a Muslim guest of the association (Wahab, 2020). Surprisingly, even the End SARS protest by the youths in the South was not accorded similar attention by the Northern youths who rather protested against the proscription of SARS (Oyewole, 2020). At the background of all is religious sentiments. As long as this subjective attitude continue, the quest of the nation to exit backwardness, poverty, maladministration and miseries remain a mirage.

\section{Recommendations}

There is no doubt that religious conflict has become one of the defining characteristics of Nigeria. This is because as noted by Toure (2003) and Odukoya (2016), there is hardly any month passes-by that the nation did not experience between two to three religious conflicts particularly in the northern part. Even though the problem has become widespread, there is a bright prospect for the country overcoming the recurrent embarrassment caused by repeated religious violence. Below are some of the suggested solutions to the problem of religious violence in Nigeria.

\section{a) Return to Constitutionalism}

Constitutionalism refers to strict adherence to constitutional provisions by a people. Nigeria has one of the best constitutions in Africa because her constitution clearly spells out the rights and obligations of all citizens as well as the duties of the state to her citizens. The problem with Nigeria and her government over the years is relegating the constitution to the background when making and implementing policies. The political elites and influential individuals appear to be a constitution in themselves. Nigeria has for most of her life as a sovereign state lived in a state of anomie. During the military era, the constitution was always suspended. Even though we have practiced democracy consistently for two decades now, most Nigerians have failed to forsake their military orientation as we still live like people without a constitution even under a democratic setting (Onyeonoru, 2002).

The constitution of the Federal Republic of Nigeria 1999 as amended unequivocally states in chapter 1 section 10 that, "The government of the Federation or a State shall not adopt any religion as a state religion". The section 38 (1) further 
elucidate on citizen's rights to a religion of their choice unhindered. Yet, the constitutional provisions appear to exist only on paper and not in practice in Nigeria. Following the action of the onetime governor of Zamfara state on 27 October, 1999, many states in Northern Nigeria have chosen Sharia (an Islamic jurisprudence) as their state religion. Religion backed by ethnicity has in the past decades become the major source of social identity in Nigeria. This development has created among the citizens particularly in the north the feeling of $U s$ and Them. This has further created another criterion for acceptance and rejection of citizens in social relations (Kukah, 1994; Toure, 2003). Aside from this direct affront, the Federal government has in principle adopted Christian and Islamic religions as state religions. The strength of any of the two religions to command the psyche of Nigerians is dependent upon the religion of whoever occupies the seat of government at the State House. The preference of the state for these religions in a volatile multi-religious Nigeria has manifested in the building of places of worship for the duo in Abuja as well as the recruitment and remuneration of the clergies whose followers enjoy annual pilgrim sponsorship to Israel and Saudi Arabia. Similarly, important National celebrations like the National day is often heralded by Jumaat prayers at National Mosque and concluded by Sunday services at the Ecumenical Center built and maintained by the Federal government.

The implication of this development is that, the clergies organize their followers to enthrone or sustain their compatriots in politics so that they can remain relevant and build the hegemony that they can use to scheme out or victimize non-adherents. This has been the basis for the "cold war" between religious groups in northern Nigeria (Kukah, 1994; Toure, 2003). If Nigeria must exit this quagmire, its political leaders must be courageous enough to implement the constitution to the letter and as much as possible down-play religion in public life. The government should only give free hands to citizens to practice their religions but must not be linked in any way to encouraging the propagation of any religion (Jannah, 2017).

\section{b) Withdrawal of Preference for Religions}

As noted earlier, the Christian and Islamic religions have over the years enjoyed ambiguous relevance in a multi-religious Nigeria (Akinola, 2016). This singular act of the Federal government no doubt negates the constitution of the Federal Republic of Nigeria. It is no doubt the basis of the struggles for supremacy among religions which have often turned violent. The Federal government can solve this daunting problem by withdrawing the erstwhile prominence given to them. Let every religion work out their relevance through the practice and piety.

\section{c) Decisive and Fair Handling of Religious Conflicts}

Imam (2004) has placed at the doorstep of governments and leadership in society the blame for repeated clashes between religious groups in Nigeria. The government and her agencies of social control have been accused for indecisive and subjective handling of previous religious conflicts, thereby creating the de- 
sire for vengeance and reprisal attacks by aggrieved persons. The aftermath has often been destructive (Kukah, 1994). Following from the fact that religion has become a channel for identity and politician often resort to using religion to achieve political relevance once in office, objectivity in addressing religious crises by public officials have become weak, especially where such conflicts affect the religions of those in power. If sentiment do not find its way into crisis management, and people are fairly treated during crisis, others will be deterred from repeating similar crimes in future.

\section{Conclusion}

Across generations, religion is parts and parcel of human culture and is known to have aided smooth relation of man with his physical and social environments as well as enhance social control in society. Furthermore, religion as popularly viewed, has potent value in unifying a people into single moral community. In other words, it has the prospect of forging for a people cohesion and strength needed for development and growth. However, if religion is not well handled especially in a multicultural society like Nigeria, it is equally potent in dividing a people much the same way it binds (Giddens, 2009). For Nigeria a purely multicultural society which have suffered from repeated cases of religious intolerance leading to violence in several parts, the political class as well as the leaderships of various religions must seek to stay within the ambit of secularism entrenched in the constitution. Leaders at all levels must endeavour to separate religion from politics so as to douse the existing tension between groups. Public office holders should not prefer any religion nor seek to sponsor adherents of any of the religions. They must allow objectivity and fairness to be the basis for addressing religious conflicts among groups if the resource studded Nigeria must be on the path to development. Furthermore, religious leaders should aspire to grow/expand their religions through piety and personal convictions of prospective converts.

\section{Conflicts of Interest}

The authors declare no conflicts of interest regarding the publication of this paper.

\section{References}

(2000). Collins Dictionary of Sociology. Glasgow: HarperCollins Publishers.

Abimboye, D. (2009). The Damage Religious Crises Have Done to the North. Lagos: Newswatch.

Akinola, G. A. (2011). Ambiguous Relevance of Nigeria's Adopted Alien Religions. Ibadan: Institute of African Studies, University of Ibadan.

BBC News (2004). Nigeria Leads in Religious Belief.

Constitution of the Federal Republic of Nigeria, 1999, with Amendments 2011.

Crampton, E. P. T. (1976). Christianity in Northern Nigeria. London: Geoffrey Chapman Books.

Giddens, A. (2009). Sociology (6th ed.). Cambridge: Polity Press.

Human Right Watch (2005). Attitudes towards Policing and Police Reform. 
Human Right Watch (2018). Nigeria: Events of 2017. http://hrw.org/world-report/2018/country-chapters/nigeria

Human Rights Watch (2019). Nigeria: Heightened Insecurity Threatens Rights: Slow Progress on Justice for Security Forces Abuse. https://www.hrw.org

Ibrahim, I. (2011). Sheriff on the Run: Former Borno State Governor Ali Modu Sheriff Flees the Country as He Is Fingered as One of the Financial Backers of Boko Haram. Insider Weekly, 5th December, 2011.

IDMC (2018). Mid-Year Reports on Internally Displace Persons in Nigeria. http://www.internal-displacement.org/mid-year-figures

Imam, Y. O. (2004). Religious Crises and Social Disruption in North-Eastern Nigeria. Ibadan: Loud Books (Publishers).

Jannah, C. (2017). Group Blast FG for Sponsoring Nigerian Pilgrims to Mecca, Jerusalem. http://dailypost.ng/2017/11/15/group-blast-fg-sponsoring-nigerian-pilgrims-mecca-jerus $\underline{\text { alem }}$

Kendall, D. (1996). Sociology in Our Times. Belmont, CA: Wadsworth Publishing Company.

Kukah, M. H. (1994). Religion, Politics and Power in Northern Nigeria. Ibadan: Spectrum Books Limited.

Odoma, S. U. (2014). The Believer-Unbeliever Saga and Violent Religious Crises in Northern Nigeria. Global Journal of Interdisciplinary Social Sciences, 3, 221-228.

Odukoya, O. A. (2016). Ethnic and Religious Crises in Nigeria. http://www.accord.org.za/ajcr-issues/ethnic-religious-crises-nigeria

Oke, E. A. (2002). An Introduction to Social Anthropology. Ibadan: Agbo Areo Publishers.

Olatunji, D. (2014). Obasanjo Warns against Muslim-Muslim and Christian-Christian Ticket. Lagos; Vanguard.

Onwuejeogwu, M. A. (1992). The Social Anthropology of Africa; an Introduction. Ibadan: Heinemann Educational Books (Nigeria) PLC.

Onyeonoru, I. (2002). Anomie and Workplace Deviance: A Sociological Analysis of Bureaucratic Corruption in Nigeria. In U. C. Isiugo-Abanihe, A. N. Isamah, \& O. J. Adesina (Eds.), Currents and Perspectives in Sociology (pp. 298-318). Ibadan: Department of Sociology, University of Ibadan.

Oyewole, R. (2020). Northern Youths Oppose \#EndSARS Protest. http://www.guardian.ng/news/northern-youths-oppose-endsars-protest

Sampson, I. T. (2012). Religious Violence in Nigeria: Causal Diagnosis and Strategic Recommendations to the State and Religious Communities. African Journal of Conflict Resolution, 12, 103-133.

Toure, K. T. (2003). Ethno-Religious Conflicts in Kaduna State. Kaduna: Human Rights Monitor.

Wahab, B. (2020). Kaduna Muslim Lawyers to Boycott NBA Conference over Withdrawal of El-Rufai's Invitation.

http://www.pulse.ng/news/local/kaduna-muslim-lawyers-to-boycott-nba-conference-o ver-withdrawal-of-el-rufais/26f687b

Wallace, A. R., \& Wolf, A. (1995). Contemporary Sociological Theory: Continuing the Classical Tradition (4th ed.). Englewood Cliffs, NJ: Prentice Hall. 